\title{
On Developing The Writing Skills Course For Accounting Students
}

\author{
Tim Firch, California State University, Stanislaus, USA \\ Annhenrie Campbell, California State University, Stanislaus, USA \\ David H. Lindsay, California State University, Stanislaus, USA \\ Don E. Garner, California State University, Stanislaus, USA
}

\begin{abstract}
The CSU, Stanislaus, accounting program is providing a new course that meets the universitywide upper-division writing requirement and offers accounting students additional professional study. While a writing skills course is not unusual in a business program, few offer an alternative centered on the accounting body of knowledge. Undergraduate students' research questions are usually not addressed before graduate study and reinforce skills learned in their regular accounting courses. Initial reactions from students have ranged from appreciation for additional time spent on accounting topics to disappointment at missing out on the "general business" writing course. Continual reassessment of the course is planned.
\end{abstract}

Keywords: writing skills course, undergraduate accounting research

\section{INTRODUCTION}

1 n 1976, the California State University (CSU) system instituted the Graduate Writing Assessment Requirement (GWAR) across the system's nineteen (now twenty-three) separate campuses [CSU, 2009]. At the time, there was general concern across the nation - not just in California - that college students were not learning how to write well enough. A 1978 article in Changing Times magazine quotes unnamed college faculty as declaring their students to be "seriously underprepared" in writing skills. The article stated that the methods then being used to teach writing were "disturbing" and consisted mostly of "underlining, circling or filling in single words. Rarely were students asked to write a paragraph, a story, or a theme" [Kiplinger, 1978].

This article discusses recent experience implementing the GWAR, specifically for accounting students within the College of Business Administration curriculum at CSU, Stanislaus, one of the smaller of the California State University campuses. Located in the California Central Valley, the campus' website indicates that CSUS offers "a wide array of majors." The campus philosophy "celebrates diversity," which is obvious in the selection of faculty, the choice of programs, and the characteristics of the student body.[CSUS, 2009].

Sections of the paper discuss The CSU Writing Proficiency Requirement, A New Writing Course for CSUS Accounting Students, The Benefits of the New Course, The Outcomes and Challenges of the Course, and Summary, Conclusions and Suggestions for Future Research.

\section{THE CSU WRITING PROFICIENCY REQUIREMENT}

Because it was feared that graduating students could not display adequate writing competence, the California State University completed a policy process in the late seventies culminating in the GWAR, the systemwide Graduate Writing Assessment Requirement. Policymakers shared the belief that students needed more specific, focused, one-on-one assistance to develop their composition skills. Although the policy was developed at the system-wide level, the implementation details were left to the individual campuses. The GWAR, therefore, takes different forms on the different CSU campuses. 
All of the campuses administer a diagnostic test called the EPT or English Placement Test to incoming freshmen. Depending on the results, students may be directed to remediation in their first semester of study. Campus implementation of the GWAR policy requires additional evaluation of students at the upper division level to assure writing competence by the time of graduation.

Most campuses use some form of test of writing ability, often elaborately and rigorously scored, in implementing the upper division GWAR. Once passed, or, in on some campuses, waived, the student is eligible to graduate so long as all other baccalaureate requirements have been met. On most campuses, passing this test or getting it waived meets the GWAR requirement. Typically, only those students having difficulty passing this exam, receive tutoring or additional composition coursework.

The Stanislaus implementation of the system-wide GWAR differs from most of the other CSU campuses by following the belief that an individual student's specific career path should be considered both in evaluating the student's writing skills and in providing additional writing instruction. This is one implementation of the concept of "writing across the curriculum" or "writing across the disciplines" which has a number of adherents throughout higher education [CNU, 2009]. In some cases, the idea of "writing across the disciplines" involves including a writing component in every college course. Within the CSU, the implementation of the GWAR on the San Marcos campus most resembles this formulation. That exceeds the goal of the GWAR by requiring a significant writing project, such as a ten-page paper, in all classes rather than taking the testing approach [CSUSM, 2008].

At Stanislaus, a diagnostic writing test, like the ones used on other campuses in response to the GWAR policy, is administered during a student's third year of study. Also like procedures on other campuses, this later test is carefully graded using a team of evaluators. The results of this test, the Writing Proficiency Screening Test (WPST) assess writing ability, but not just to measure whether a student is ready for graduation. Rather, the test assesses whether the student is ready to proceed to the required upper-division course in the student's major that requires advanced composition skills. Students not passing the WPST must practice compositional writing, either through tutoring or through an additional writing course, and then take the WPST again. Only when a student has passed the WPST is the student admitted to the designated writing proficiency course which is also a requirement in that student's major area of study. Only when the student passes this "writing proficiency" (WP) course is the GWAR satisfied. This implementation of the concept of "writing across the disciplines" involves including a writing course within each discipline.

Only a few other CSU campuses currently use (or are implementing) a designated writing proficiency course within the student's major as opposed to a course provided by the Department of English. Some have Business Administration WP courses, like we have for General Business students. With the previously noted exception of CSU San Marcos, we have yet to find another course significantly like our own in tenor, in an accounting department. A WP course within the major gives the student practice writing documents consistent with the eventual professional requirements of the chosen field. At Stanislaus, class sizes for discipline-specific WP courses are kept low to assure that students get personal assistance. This limited class size is facilitated by the relatively low average class size at Stanislaus which remains below 30 students [CSUS, 2009]. Students sign up for upper-division writing proficiency courses along with registering for their other major courses, as a math major, for example, or as a business administration major.

Although the need for a writing class for some majors, such as math, may not be immediately obvious, relatively easy justifications can be found. Many CSU math majors become middle and secondary school teachers who will, in turn, need to understand how to implement writing programs at the secondary school level. Students entering industry will need to communicate adequately with management and document their work. At least some students in each academic discipline will choose to go on to graduate school where writing skills are a basic requirement.

\section{A NEW WRITING COURSE FOR CSUS ACCOUNTING STUDENTS}

This paper reports the experience with a new upper division writing proficiency course within the accounting program designed specifically for accounting students. In the past, accounting students took the same 
writing proficiency course taken by other Business Administration majors. Long taught by faculty in the English department, the WP course for business students was recently moved to the College of Business Administration and renumbered accordingly. This administrative move made it possible for the College to design and offer a course specifically for students within the accounting concentration. ${ }^{1}$

Why would accounting students, "number crunchers," need a specialized writing course? Accountants must have strong reading and writing skills to apply ever more complex accounting standards in a legal environment that requires careful documentation of business and audit judgments. The evolving nature of accounting work in a computerized environment, characterized by complex guidance and standards, has even caused the CPA exam (Uniform Certified Public Accountant Examination) to be reformulated. Now computerized, the CPA exam is more research-oriented. With research capabilities and written communication skills significant components of the new CPA exam, accounting students must practice those skills to pass. Not all students in the accounting concentration aspire to become certified public accountants. The CPA exam, however, was designed to test the skills of entry-level candidates, students just graduating with a baccalaureate and an accounting concentration [AICPA, 2002]. Therefore, the CPA exam is a fair indicator of the skill set generally expected of accounting graduates.

The Financial Accounting Standards Board has recently streamlined its body of accounting standards and made them more accessible with a new codification website [FASB, 2009]. While the availability of the new codification has made the task of researching financial accounting guidance much less burdensome, it has also raised expectations for students' abilities. Confusion with the specifics of the "House of GAAP" (if you have to ask, you don't want to know) was an understandable excuse for a student to be unsure of the controlling accounting guidance. Now that the rules, standards, and other elements of authoritative guidance for accounting are organized and accessible via the codification, students have no excuse. An accounting student today should reasonably be expected to be able to research using the new technology and organization. The student needs to be able to present and adequately justify his or her professional opinion to colleagues and clients. The goal of this campus' new writing proficiency course for accountants is to be sure that students can practice these key skills within the educational environment with a knowledgeable mentor.

\section{THE BENEFITS OF THE NEW COURSE}

As the details of implementing the GWAR were handed to each individual campus by the California State University system, so the details of designing and implementing the writing proficiency course for the accounting program were handed to the professor hired to teach the class, the lead author of this article. He was told that an accounting student should be able to research using the new technologies available. When the student finds the controlling rule for the circumstance in question, the student should be able to present and adequately justify his or her opinion to colleagues, clients and supervisors. The class should provide just this practice. To figure out how to prepare the class, the professor asked and answered two key questions:

The first question was, "How does one learn to write?" The same way one learns any skill - by studying good examples and practicing the actual skill itself. limitations.

The next question was, "How does one discover what has yet to be mastered?" By experiencing one's

The writing class was numbered right after the main portion of the accounting curriculum, the year of intermediate accounting -3110 and 3120 . Students are required at least to be concurrently enrolled in the first of these junior-level accounting courses. Fortuitously, the professor teaching the writing course had previously taught the intermediate courses and is up-to-date with that material. Thus, the writing course could be an opportunity to review and reinforce this important material while also providing an overview of accounting theory.

Usually, a little accounting theory is included in the introductory material in intermediate and advanced textbooks, but little time is dedicated to the topic. The derivation and structure of accounting standards are not

\footnotetext{
${ }^{1}$ The authors recognize Dr. Steven Filling who introduced this course to the Stanislaus campus.
} 
readily comprehensible to the students. Topics for the writing class, therefore, address the more important theoretical issues in accounting and the most easily misunderstood concepts. Throughout the writing proficiency course, we take every opportunity to review important concepts so students develop "fluency" with the dimensions of the field and become comfortable discussing its issues.

Few undergraduate accounting programs include a research or theory course. These issues are usually postponed until graduate study because there is so much material that must be covered in an undergraduate program and some of the theoretical issues are relatively abstract. That there is no set curriculum for an undergraduate research and writing course means this has been an opportunity to add some value to the entire accounting program and to help the students. It's possible to review subject matter covered in other accounting courses. It's a chance to let the students get some perspective on the material they have covered elsewhere. For example, a course like auditing is daunting in its complexity. Here is an opportunity to step back and take an overview of the goals and methods of that course and to enable students to appreciate its importance and relationship to the rest of their accounting studies. The research course is also a chance to preview difficult subjects, so students might find later courses a little easier.

The writing proficiency course has been a great opportunity to bring "soft" topics into consideration, topics that are often neglected due to the press of technical, accounting material. There are many new issues and controversies in accounting for students to consider and debate. For example, as globalization proceeds, there is more pressure on the United States to abandon its own, national accounting standards and adopt international financial reporting standards (IFRS). Some think that "convergence" or a gradual joining of U.S. and international standards is an appropriate goal while others do not. Even the SEC became involved by issuing a "road map" for eventual transition to international standards [Journal of Accountancy, 4/09]. Issues like this provide ample opportunity for student research and exposition, and an excuse to read and consider for themselves the opinions of experts on the proposed course of action. Although it's an oversimplification, it can be argued that United States accounting standards are essentially a collection of specific rules and international standards are essentially a set of principles. Thus, the IFRS emerging issue offers ample topics for writing practice as students might "compare and contrast" rules-based and principles-based accounting standards.

On a more mundane level, there are clear writing requirements for professional accountants. They need to be able to prepare concise journal entry explanations, informative footnotes, and organize financial statements. In fact, the overall process of compiling and drafting the basic financial statements is not easily addressed elsewhere in the accounting curriculum where students find themselves immersed in details. The compilation is time-consuming and better addressed as a project in a writing course than as an examination topic in a typical accounting course. In this course, accounting students work with research resources, databases, web site and library resources as do students in other writing courses across the university.

\section{THE OUTCOMES AND CHALLENGES OF THE COURSE}

Some students, generally those who are closer to graduating or taking the CPA exam, have indicated that they like the additional review the new course offers and the opportunity to get a fuller understanding of the issues discussed. Other students complain that the class forces them to deal with advanced topics when they believe it should be strictly a junior-level course. As this course comes earlier in the program for some students than others, having a mix of students in the class has sometimes been a problem. This may be unavoidable because some students take longer to pass the WPST test or delay sitting for the WPST test, which must be passed before students can take any upper division writing proficiency course on this campus, including the one for accounting students. To deal with this, the professor gives some of the more advanced, complex problems relatively lighter weights in the final grade. The grading rubric focuses on writing outcomes and adjusts for the varying levels of the students accounting skills. Items that even a new student should be able to work out are weighted with more points, and the scoring rubric considers composition and presentation issues along with content.

A more difficult problem to solve has been the lack of adequate text material. Some very good material has been made obsolete by the new FASB codification and up to date material has not yet appeared. Texts that had been designed to be used with the old Financial Accounting Research System (FARS) database can no longer be used now that the FASB codification is available [Wallace, 2005]. 


\section{SUMMARY, CONCLUSIONS AND SUGGESTIONS FOR FUTURE RESEARCH}

In response to the CSU system-wide GWAR requirement, and to the CSU, Stanislaus campus' implementation of "writing across the curriculum," the Accounting Department created a new course; i.e., Accounting Research and Communication. This upper-division writing proficiency course gives students an opportunity to write within the discipline, while obtaining experience in researching the authoritative literature. Students are asked accounting theory questions and, after referring to the FASB Codification, compose essays in response. Interestingly, there are some commonalities between this course and the old accounting theory courses offered in undergraduate accounting curricula decades ago; i.e., courses that fell by the wayside as the amount of accounting material has expanded.

It is too early to determine whether this course design is successful. Further research is needed on the efficacy of this and other accounting writing courses. As a first step, a survey should be conducted on the frequency and types of accounting writing courses offered nationwide. While there is a lot of information available about college writing courses in general, little is known about how accounting programs are addressing the writing proficiency challenge. Once identified, it would be possible to evaluate the teaching outcomes of these courses. One possible criterion would be to measure whether students completing such a course exhibit improved performance on professional exams like the CPA exam.

\section{REFERENCES}

1. AICPA, American Institute of Certified Public Accountants, Board of Examiners [2002] Uniform CPA Examination Content Specifications, p.2.

2. AICPA, American Institute of Certified Public Accountants, [2009] Highlights, Journal of Accountancy, volume 207, issue 4, p. 12.

3. California State University: Office of Public Affairs, Historic Milestones, retrieved 12/5/09 from http://www.calstate.edu/PA/info/milestones.shtml

4. California State University: Office of Academic Affairs, A Review of the CSU Graduation Writing Assessment Requirement, retrieved 12/5/09 from http://www.calstate.edu/acadaff/GWAR 2002_AppE.shtml

5. CSUS: California State University, Stanislaus: Academics, retrieved 12/6/09 from http://www.csustan.edu/academics/About us, retrieved 12/6/09 from http://www.csustan.edu/aboutus/ Class size, President's Budget Forum, 2/6/09, retrieved 12/6/09 from http://www.csustan.edu/budget/documents/BudgetForum012109.pdf

6. CSUSM: California State University, San Marcos: WASC (Western Association of Schools and Colleges) documentation, retrieved 12/9/09: http://www.csusm.edu/ipa/wasc/tables_2008/table-7.1.pdf

7. CNU: Christopher Newport University, Writing Across the Curriculum Collection of Online Articles, retrieved 12/5/09 from http://www.cnu.edu/wcenter/wac/articles.html

8. Emory University: Goizeta Business School, “Accounting -- the House of GAAP” definition, retrieved 12/5/09 from http://business.library.emory.edu/info/accounting/gaap.html

9. FASB: Financial Accounting Standards Board, Accounting Standards Codification, retrieved 12/5/09, http://asc.fasb.org/

10. Kiplinger Washington Editors [1978] Why our schools went wrong, Changing Times, Volume 32, Number $5, \mathrm{p} 25$

11. Wallace, Wanda [2007] Mastery of the Financial Accounting Research System (FARS) Through Cases, 2nd edition, John Wiley \& Sons.

12. Young, A. [1999] Teaching Writing Across the Curriculum, third edition. Upper Saddle River, NJ: PrenticeHall. 
NOTES 